\title{
Novo ou velho? O ensino superior e a Ciência*
}

$\mathrm{S}$ aldou-se por um sumário desapareclMEnTo político a experiência de colocação da ciência como sector vertical (como ministério) do executivo. Saudada por alguns como uma autêntica "revolução na ciência» (manchete de um dos jornais diários de grande circulação na altura) no entanto, será que este arranjo governativo terá conduzido a uma alteração radical na percepção dos portugueses quanto à necessidade e ao valor da ciência?

Quando se falou de um ministério para a ciência, em 1994 e 95, era com a ideia de se conseguir reestruturar o sistema de ciência e tecnologia em Portugal, isto é, de reforçar as instituições nos sectores públicos, dotá-las de novas missões e de novos quadros, adequados aos tempos de globalização que vivemos, ligá-las e forçar a sua interacção com as actividades económicas, com a sociedade, com a educação e com a cultura.

Pensou-se que era tempo - duas décadas depois do 25 de Abril e dez anos após a integração no quadro das instituições europeias - de tornar a ciência no nosso país pertença colectiva e, portanto, que era tempo de introduzi-la como assunto da agenda política.

Se a modernização, a produtividade e a competitividade, chaves do desenvolvimento económico e social dos nossos parceiros no mundo ocidental, tinham como base a ciência e a sua eficaz contribuição para a produção de novas tecnologias, então, era preciso que também no nosso país semelhantes atitudes, preocupações e procedimentos, fossem acarinhados e promovidos.

Pensou-se que finalmente se ia valorizar a ciência como uma actividade comunicacional alargada, fundamento de uma cultura viva e confiante no futuro, elemento essencial de uma visão do mundo construtiva e solidária, base de um progresso económico norteado por saudáveis princípios de sustentabilidade.

Para isso, precisávamos de uma sólida e forte comunidade científica, segura da sua identidade, debatendo os seus problemas e as questões de soberania nacional, reconhecendo as especificidades do quadro académico e da investigação científica básica, as necessidades da aprendizagem da ciência nas escolas, bem como o quadro operativo da investigação e das aplicações tecnológicas nas empresas, as grandes linhas da discussão pública internacional sobre ciência e tecnologia e os contornos da organização e gestão das actividades científicas.

Isto é, teria que ser feita uma verdadeira "cruzada" pela, e com, a ciência, afirmando que fazer ciência não é só investigar, mas também aplicar, ensinar, divulgar e gerir. Esclarecendo que a ciência só pode viver neste mundo alargado, globalizado e comunicacional, se a circulação de conhecimentos for intensa e sistemática entre estas várias formas complementares e articuladas da actividade científica. Em suma, reconhecer que fazer ciência é tudo isto: investigar; aplicar; comunicar, transferir $e$ divulgar; ensinar e aprender; gerir e administrar.

Só assim, com uma comunidade de praticantes entendendo o objectivo estratégico do seu esforço diário, se conseguiria que a ciência chegasse aos que diariamente contactam com os seus membros nas mais diversas instituições que integram a sociedade moderna, da economia às instâncias políticas, dos serviços às entidades do foro cultural. Só deste modo haveria a possibilidade de colectivamente se entender o papel e o contributo da ciência para as trajectórias societais que se fossem percorrendo rumo ao futuro.

Era para fazer vingar esta perspectiva de longo prazo da actividade científica que se tornava necessário instituir um ministério. Porque se o objectivo fosse essencialmente afirmar a qualidade da investigação universitária que se pratica em Portugal, então outras estruturas governativas mais eficazes e adequadas estavam disponíveis como modelo, tanto cá, como por essa Europa fora.

Do ponto de vista político muito pouco mais se viu para além do interesse na relação da ciência com o ensino, conforme algumas vozes, raras, cedo alertaram. Apesar do apoio e dos recursos comunitários, a verticalização governativa da ciência não favoreceu que os outros sectores se empenhassem na sua promoção e desempenho.

De facto, qual o conhecimento que temos quanto ao nivel de participação da ciência portuguesa na agricultura? ou nas pescas? nos transportes? na in-

\footnotetext{
* Texto publicado no Jornal de Letras, Artes e Ideias de 17 de Abril de 2002
} 
dústria? nos serviços? nas obras públicas? nas telecomunicaçōes? no ambiente? na habitação? na cooperação internacional?

Apenas na área do ensino superior temos indicadores sólidos e claros dos progressos havidos nos últimos anos.

Por este motivo não nos devemos admirar com o facto de a ciência aparecer associada ao ensino superior no governo que acaba de ser empossado. 0 ensino superior é o único sector de actividade em Portugal que, no seu todo, entende e precisa do contributo da actividade cientifica.

Não tendo sido demonstrada publicamente mais nenhuma virtude para a ciência no nosso país durante o periodo em que o mundo furiosamente se globalizou, a ciência recolhe ao seio universitário para se recompor.

Então, e o Ciência Viva e a "sociedade da informação"? Aç̧ões meritórias, sem dúvida, mas que escondem a falta de apoio a outras iniciativas emanadas da sociedade civil nestes domínios; para escolher um exemplo: porque razão a ACTD, depois transmutada em ADCT (Associação para a Difusão da Ciência e Tecnologia) se extinguiu sem qualquer rumor, nem mais tentativas para gerar outras actividades de teor semelhante?

Ombreando e escondendo a acção positiva de divulgação científica e de apoio ao ensino experimental do Ciência Viva e do seu Pavilhão do Conhecimento avulta a inoperância dos orgãos consultivos para a ciência, em particular a do CSCT (o Conselho Superior de Ciência e Tecnologia). Nos últimos seis anos, nunca o CSCT reuniu, nem emitiu qualquer parecer. Nem sequer foi nomeado um presidente.

É evidente que esta situação não aconteceu por acaso. Nem por distracção dos responsáveis a nível governamental. o Conselho não reuniu porque houve vontade política de que não reunisse. Quis-se que não houvesse outros pareceres nem opiniões para além dos emitidos pelos orgãos oficiais da administração. E, assim, a sociedade civil portuguesa continuou a olhar para a ciência como uma curiosidade, nalguns casos como um divertimento e noutros, mesmo, como uma maldição (parafraseando o titulo de uma conhecida reflexão sobre a relação da ciência com a sociedade). Enquanto o mundo, lá fora, se transformava; para melhor e para pior, como é habitual.

Não se preparou, pois, a sociedade civil nem aquela que é o seu reflexo, a sociedade politica, para os aspectos negativos, conflituais, perversos, que o desenvolvimento das aplicações tecnológicas da ciência foi dando lugar. Ou seja, o que é ainda pior, deixou-se que os cidadãos se desembrulhassem, como de costume, pelos seus próprios meios, isto é, recorrendo aos media.

Não houve nenhum grande debate nacional sobre política cientifica, nem sobre o papel da ciência nos domínios da defesa, da energia, do desenvolvimento sustentável, da regulação ou da administração pública. Nas campanhas eleitorais, autárquicas, legislativas ou europeias, a ciência nunca surgiu como tema.

Ao contrário do que se passa na Europa a que nós pertencemos. A revista Futuribles publica no seu número de Março deste ano uma lista de doze questões maiores a colocar aos candidatos à próxima eleição para presidente da República Francesa. Doze questões que a comissão de redacção da revista considera essenciais para o futuro daquele pais, um país que vive num regime quase presidencial.

Uma dessas doze questões é a de que tipo de política para a investigação científica é defendida pelo candidato, e nela perpassam os problemas que se põem a uma sociedade europeia avançada que se vê envolta nos turbilhões da globalização financeira e dos mercados: como mobilizar os recursos necessários para estimular os agentes inovadores a garantir o futuro.

Como se mostra, o mundo dos outros (que, afinal, é o nosso) não pára. Urge, pois, atribuir à ciência o seu papel real na sociedade. Sob pena de não conseguirmos ser mais do que figurantes de uma peça escrita numa língua que não falamos. Sob pena de continuarmos amarrados, engranitados, nas soberbas dos séculos passados.

\begin{abstract}
"These chemicals we desire and fear (chemists call them compounds or molecules, once they are reasonably pure) are not the largest (the realm of astronomy), nor the smallest (part of physics). They are squarely, nicely, in the middle, on our human scale. Which is why we care about them, not as distanced, hypothetical constructs, but in this world. Those molecules, of pharmaceutical or pollutant, are of just the right size to interact, for better or for worse, with the molecules of our bodies.
\end{abstract}

That a reasonable human being can be ambivalent about chemicals, seeing in them both harm and benefit, is not a sign of irrationality but of humanity. Utility and danger are two poles of a duality. Any fact in our world is evaluated, often subconsciously, by our wonderfully rational and irrational mind, in terms of such polarities. Only if one is dead to experience does one fail to ask the dual question - "Can it help me?" / "Can it hurt me?" Asking that question endows the object of the query, the "it", with a kind of life. It is linked to you. The tension of the object being harmful, or harmless, or maybe both, makes it interesting. The etimology of "interest" is from inter and esse, to be inbetween. The tension of asking the question and struggling with the answer links the material and spiritual worlds."

do Prefácio de The Same and Not the Same, Roald Hoffmann 


\section{Eur \\ European Journal of Inorganic Chemistry}

\section{Yourjournal}

First Impact Factor: 2.222

Rapid publication times especially for short communications France, Germany, Greece, Hungary - together with the Hungarian Academy of Sciences, Italy, The Netherlands, Portugal, Spain)

Authors' work exhibited on the cover

Attractive personal member subscription rates available;

see: wwww.EurJIC.com

More color

\section{European Journal of Inorganic Chemistry}

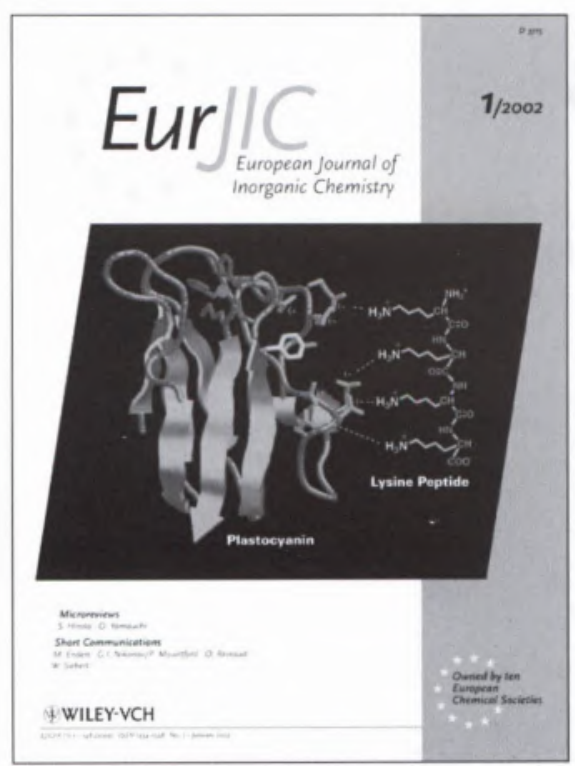

Wiley-VCH

200212 issues

ISSN Print 1434-1948

ISSN Electronic 1099-0682

The European Journal of Inorganic Chemistry publishes full papers and short communications on the entire spectrum of inorganic and organometallic chemistry. These contributions are supplemented by microreviews - introducing readers to one specific area of an author's research by means of a detailed overview of one selected topic. Senior Editor: Ivano Bertini (Italy)

The European Journal of Inorganic Chemistry is available online through Wiley InterScience. Visit Wiley InterScience (www.interscience.wiley.com) for complete details and see the FREE full text virtual sample copy. Now supported by ten national chemical societies (Belgium,

Order Your Copy now:

Just copy, fill in and fax to: +49/(0)6201/606-172

\lrcorner Please send me a free sample print copy

\lrcorner Please enter our $/$ my 2002 subscription to: European Journal of Inorganic Chemistry

2002, ISSN Print 1434-1948 2002, ISSN Electronic 1099-0682 at the institutional rate*

$$
\begin{aligned}
& \text { print electronic } \\
& \lrcorner \text { Europe } J € 1868 \quad J € 1868 \\
& \text { 」Switzerland 」 sFr } 3258 \text { J sFr } 3258 \\
& \lrcorner \text { All other } \\
& \text { countries JUS\$2308 JUS\$ } 2308
\end{aligned}
$$

For members of the owner societies from Belgium, France, Germany, Greece, Hungary, Italy, The Netherlands, Portugal and Spain, at the personal rate:

$$
\begin{aligned}
& \lrcorner \text { Europe } \quad J \in 218 \\
& \lrcorner \text { Switzerland }\lrcorner \mathrm{sFr} 458 \\
& \lrcorner \text { All other } \\
& \text { countries }\lrcorner \text { USS\$248 }
\end{aligned}
$$

Prices include postage and handling charges.

Please tick: $\square$ private $\square$ business

Name

Address

City/Postcode

Country

Membership-No.

Date/Signature

Please return this order to your local bookseller or to:

Customers in Germany, Austria and Switzerland:

Wiley-VCH Customer Service

P.O. Box 101161

D-69451 Weinheim, Germany Phone: +49 (0) 6201-606147

Fax: +49 (0) 6201-606172

e-mail: subservice@wiley-vch.de

Customers in all other areas: John Wiley \& Sons, Ltd.

Journals Administration Department 1 Oldlands Way

Bognor Regis West Sussex, P022 9SA, England

Phone: +44 (0) 1243-779 777

Fax: +44 (0) 1243-843232

e-mail:cs-journals@wiley.co.uk 